\title{
Isolation and functional characterization of an allatotropin receptor from Manduca sexta
}

\author{
Frank M. Horodyski ${ }^{\mathrm{a}, *}$, Heleen Verlinden ${ }^{\mathrm{b}}$, Nanda Filkin ${ }^{\mathrm{a}}$, Hans Peter Vandersmissen ${ }^{\mathrm{b}}$, \\ Christophe Fleury ${ }^{c}$, Stuart E. Reynolds ${ }^{c}$, Zhen-peng Kai ${ }^{a}$, Jozef Vanden Broeck ${ }^{b}$ \\ ${ }^{a}$ Department of Biomedical Sciences, College of Osteopathic Medicine, 228 Irvine Hall, Ohio University, Athens, OH, USA \\ ${ }^{\mathrm{b}}$ Molecular Developmental Physiology and Signal Transduction, Zoological Institute, K.U. Leuven, Naamsestraat 59, B-3000 Leuven, Belgium \\ ${ }^{\mathrm{c}}$ Department of Biology and Biochemistry, University of Bath, Bath BA2 7AY, UK
}

\section{A R T I C L E I N F O}

\section{Article history:}

Received 1 December 2010

Received in revised form

1 June 2011

Accepted 6 June 2011

\section{Keywords:}

Allatotropin

Manduca sexta

$G$ protein-coupled receptors

Neuropeptides

Juvenile hormone

\begin{abstract}
A B S T R A C T
Manduca sexta allatotropin (Manse-AT) is a multifunctional neuropeptide whose actions include the stimulation of juvenile hormone biosynthesis, myotropic stimulation, cardioacceleratory functions, and inhibition of active ion transport. Manse-AT is a member of a structurally related peptide family that is widely found in insects and also in other invertebrates. Its precise role depends on the insect species and developmental stage. In some lepidopteran insects including $M$. sexta, structurally-related AT-like (ATL) peptides can be derived from alternatively spliced mRNAs transcribed from the AT gene. We have isolated a cDNA for an AT receptor (ATR) from $M$. sexta by a PCR-based approach using the sequence of the ATR from Bombyx mori. The sequence of the M. sexta ATR is similar to several $G$ protein-coupled receptors from other insect species and to the mammalian orexin receptor. We demonstrate that the $M$. sexta ATR expressed in vertebrate cell lines is activated in a dose-responsive manner by Manse-AT and each Manse-ATL peptide in the rank order ATL-I > ATL-II $>$ ATL-III $>$ AT, and functional analysis in multiple cell lines suggest that the receptor is coupled through elevated levels of $\mathrm{Ca}^{2+}$ and cAMP. In feeding larvae, Manse-ATR mRNA is present at highest levels in the Malpighian tubules, followed by the midgut, hindgut, testes, and corpora allata, consistent with its action on multiple target tissues. In the adult corpora cardiaca-corpora allata complex, Manse-ATR mRNA is present at relatively low levels in both sexes.
\end{abstract}

(c) 2011 Elsevier Ltd. All rights reserved.

\section{Introduction}

Juvenile hormone $(\mathrm{JH})$ is a sesquiterpenoid that possesses numerous developmental and physiological functions in insects, including the regulation of molting and metamorphosis in immature insects (Riddiford, 1994) and the control of reproductive events and egg maturation in adult insects (Wyatt and Davey, 1996). The control of JH levels in the insect hemolymph is achieved, in part, by neuropeptides that stimulate or inhibit its biosynthesis by the corpora allata (CA), allatotropin (AT) and allatostatin (AST), respectively (Weaver and Audsley, 2009). A great deal of progress has been made in the characterization of these neuropeptides using biochemical methods and physiological assays performed in vitro. More recently, major advances in studying the full complement of neuropeptides in insects came with the utilization of bioinformatic tools to predict the genes encoding neuropeptides from genome

\footnotetext{
* Corresponding author. Tel.: +1 740593 0851; fax: +1 7405972778.

E-mail address: horodysk@ohio.edu (F.M. Horodyski).
}

sequences and EST libraries. Neuropeptides can occur as unique components or as members of families based on their sequence similarity whose members often have similar functions.

Insect neuropeptides were first characterized by their biochemical isolation, structural elucidation, and activity in a number of bioassays; and were usually named based on their first known biological activity. AT was first characterized in the tobacco hornworm, Manduca sexta, (and designated Manse-AT) based on its ability to stimulate $\mathrm{JH}$ biosynthesis in the CA of adult, female lepidopteran insects in vitro (Kataoka et al., 1989). Subsequently in M. sexta, it was shown that Manse-AT possesses cardioexcitatory activity in pharate adults (Veenstra et al., 1994) and inhibits active ion transport across the larval midgut epithelium in vitro (Lee et al., 1998). Additional functions for Manse-AT in other lepidopterans include the stimulation of JH biosynthesis by the larval CA in some, but not all, lepidopteran insects (Audsley et al., 2000; Li et al., 2002), stimulation of foregut contractions in Helicoverpa armigera and Lacanobia oleracea (Duve et al., 1999, 2000), and the stimulation of ventral diaphragm oscillation in Pseudaletia unipuncta (Koladich et al., 2002). Additional activities were described for 
Manse-AT, or the endogenous homolog, in other insects including the stimulation of $\mathrm{JH}$ biosynthesis by CA of insects from the orders Diptera (Tu et al., 2001; Veenstra and Costes, 1999), Hymenoptera (Rachinsky and Feldlaufer, 2000), Dermaptera (Rankin et al., 2005) and Coleoptera (Abdel-latief and Hoffmann, 2010); the stimulation of myotropic activity in insects from the orders Orthoptera (Paemen et al., 1991), Dictyoptera (Rudwall et al., 2000), Coleoptera (Spittaels et al., 1996), and Hemiptera (Santini and Ronderos, 2007); and the photic entrainment of the circadian clock in an insect from the order Dictyoptera (Petri et al., 2002). Like many neuropeptides, Manse-AT has multiple functions, and its primary role may differ depending on the developmental stage of the insect.

Manse-AT is a member of a peptide family that has been isolated from numerous insect species, deduced from the sequences of homologous genes, or identified in silico from nucleotide sequence databases (Elekonich and Horodyski, 2003; Weaver and Audsley, 2009). Related peptides have been isolated from mollusks (Harada et al., 1993; Li et al., 1993) and annelids (Ukena et al., 1995) based on their myotropic activity, and it has been suggested that the ancestral role for this peptide family is related to its myotropic role (Elekonich and Horodyski, 2003). Despite its widespread appearance in numerous insects, the AT sequence has not been identified in Drosophila melanogaster or other members of that genus (Hewes and Taghert, 2001; Vanden Broeck, 2001), or in the hymenopteran insects Apis mellifera (Hummon et al., 2006) or Nasonia vitripennis (Hauser et al., 2010). In some lepidopteran insects including $M$. sexta, multiple mRNAs that differ by alternative splicing are transcribed from the AT gene in a stage- and tissuespecific manner and predict the presence of peptides that are structurally related to Manse-AT [ATL peptides; (Abdel-latief et al., 2003; Horodyski et al., 2001; Sheng et al., 2007; Yin et al., 2005)], and whose biological activities overlap with those of Manse-AT (Lee et al., 2002).

Neuropeptides exert effects on their cellular targets by binding to high affinity receptors, the vast majority of which are members of a large family of structurally-related proteins that possess seven hydrophobic membrane-spanning regions, the $G$ protein-coupled receptors (GPCRs). Ligand binding transduces a signal mediated by activation of a GTP-binding protein (G protein) that leads to alterations in the levels of second messengers that, in turn, exert functional changes in the target cell and the organism. The specificity of GPCRs is generally determined by expression of the GPCR in a heterologous cell line or in Xenopus oocytes, and the subsequent demonstration of ligand-dependent changes in second messengers that are monitored by the quantification of their levels, expression of reporter gene constructs, or the opening of channel proteins. The characterization of neuropeptide GPCRs has also been greatly advanced by the use of molecular tools and the determination of genome sequences to identify similar GPCRs in different insects which respond to the homologous neuropeptide.

The AT receptor (ATR) was first identified in the silkmoth, Bombyx mori, (Bommo-ATR) by the systematic screening of GPCRs that were highly expressed in the corpora cardiaca-corpora allata (CC-CA) complex with neuropeptides in a heterologous expression system (Yamanaka et al., 2008). Transcript levels of Bommo-ATR were determined in multiple tissues at two larval stages by quantitative RT-PCR (qPCR), consistent with the multiple functions of the peptide. Bommo-ATR mRNA levels differed between the two larval stages, and levels were highest in the $\mathrm{CC}-\mathrm{CA}$, brain, epidermis, and testes. In situ hybridization demonstrated that Bommo-ATR mRNA was present in the CC, but not the CA.

We used the sequence of Bommo-ATR to design oligonucleotide primers to isolate the homologous GPCR from M. sexta (ManseATR). In order to determine if Manse-ATR reacted to Manse-AT or the Manse-ATL peptides, we expressed Manse-ATR in a heterologous cell line and tested whether these peptides activate the Manse-ATR and then determined their relative potencies. We showed that Manse-AT and each Manse-ATL mediated peptidedependent responses in a dose-responsive manner at high affinity. Each of the Manse-ATL peptides exhibited a higher potency to Manse-ATR than Manse-AT. Then, to determine which second messenger the receptor is coupled to, Manse-ATR was expressed in other cell lines to demonstrate that the receptor activation increases both cAMP and $\mathrm{Ca}^{2+}$ levels suggesting that it may act through two distinct $G$ proteins.

\section{Materials and methods}

\subsection{Insects}

Larvae of the tobacco hornworm, M. sexta, were reared individually on an artificial diet (BioServ) at $25^{\circ} \mathrm{C}$ under a long-day (16L:8D) photoperiod (Bell and Joachim, 1976). The day of ecdysis to the fifth larval instar is designated day 0. Wandering larvae, characterized by the appearance of a prominent dorsal vessel, were collected and transferred to plastic vials with vermiculite. These larvae molted into pupae 5 days later. Pharate adults were selected when the pupal cuticle above the wing is dark and soft (Schwartz and Truman, 1983) and transferred to a wooden growth chamber containing a tobacco plant and $10 \%$ sucrose at $25^{\circ} \mathrm{C}$ under a longday (16L:8D) photoperiod where the adult moths emerged. Eggs were collected daily from the leaves of the tobacco plant and placed in a petri dish in the larval growth chamber overlaid with a metal mesh screen and artificial diet inside a covered plastic chamber, in which the larvae were allowed to hatch. For the collection of adult CC-CA complexes, pharate adults were separated by sex and placed in different chambers in which the moths enclosed.

\subsection{Isolation of the ATR CDNA}

Midguts from day 0, fifth instar larvae were dissected in Manduca saline buffer (Riddiford et al., 1979) and stored overnight at $4{ }^{\circ} \mathrm{C}$ in RNA later (Ambion) followed by removal of the solution and storage of the tissue at $-80{ }^{\circ} \mathrm{C}$. RNA was extracted using Trizol reagent (Gibco-BRL) and Poly $\mathrm{A}^{+}$RNA was selected using the PolyATract mRNA Isolation System III (Promega). Then, cDNA was synthesized using Stratascript reverse transcriptase (Stratagene) with $0.15 \mu \mathrm{g}$ poly A ${ }^{+}$RNA using a Random Primer (Promega). A 64fold degenerate sense primer, $5^{\prime}$-GT(ACGT)GC(ACGT)GA(CT)TT(CT) ATGGT-3' (S-DEG) was designed from the sequence VADFMV present within transmembrane domain II (TM-II) of B. mori BNGRA16 (Yamanaka et al., 2008). A 256-fold degenerate antisense primer, 5'-A(AG)(AG)TG(ACGT)AC(ACGT)GG(AG)AA(AG)TA-3' (AS$D E G$ ) was designed from the amino acid sequence YFPVHL present in the TM-VI of B. mori BNGR-A16. We utilized a touchdown PCR protocol (Don et al., 1991) in which the annealing temperatures were gradually decreased to prevent mispriming and preferential amplification of undesirable alternate products. The PCR reaction was performed with approximately $1 \mathrm{ng}$ of cDNA as a template in PCR buffer (Stratagene) containing $2 \mathrm{mM} \mathrm{MgCl}, 0.2 \mathrm{mM}$ dNTPs, and $0.4 \mu \mathrm{M}$ of each primer in $50 \mu \mathrm{l}$. After an initial denaturation step at $94{ }^{\circ} \mathrm{C}$ for $4 \mathrm{~min}$, the mixtures were amplified in a thermal cycler (Perkin-Elmer 480 ) for 3 cycles $\left(94^{\circ} \mathrm{C}, 45 \mathrm{~s} ; 60^{\circ} \mathrm{C}, 45 \mathrm{~s} ; 72^{\circ} \mathrm{C}, 45 \mathrm{~s}\right)$, followed by 3 cycles $\left(94{ }^{\circ} \mathrm{C}, 45 \mathrm{~s} ; 55^{\circ} \mathrm{C}, 45 \mathrm{~s} ; 72{ }^{\circ} \mathrm{C}, 45 \mathrm{~s}\right)$, followed by 3 cycles $\left(94^{\circ} \mathrm{C}, 45 \mathrm{~s} ; 50{ }^{\circ} \mathrm{C}, 45 \mathrm{~s} ; 72{ }^{\circ} \mathrm{C}, 45 \mathrm{~s}\right)$, followed by 40 cycles $\left(94^{\circ} \mathrm{C}, 45 \mathrm{~s} ; 47^{\circ} \mathrm{C}, 45 \mathrm{~s} ; 72{ }^{\circ} \mathrm{C}, 45 \mathrm{~s}\right)$, followed by a 5 min final extension at $72{ }^{\circ} \mathrm{C}$. The PCR products were analyzed on a $3 \%$ NuSieve-GTG agarose (FMC Bioproducts) gel. The faint $\sim 600 \mathrm{bp}$ PCR product was excised from the gel, and reamplified for 40 cycles $\left(94{ }^{\circ} \mathrm{C}, 45 \mathrm{~s} ; 47^{\circ} \mathrm{C}, 45 \mathrm{~s} ; 72{ }^{\circ} \mathrm{C}, 90 \mathrm{~s}\right)$, preceeded by an initial 
denaturation step at $94{ }^{\circ} \mathrm{C}$ for $4 \mathrm{~min}$, and followed by a 5 min final extension at $72{ }^{\circ} \mathrm{C}$. Then $0.5 \mu \mathrm{l}$ (2.5 units) of Taq2000 (Stratagene) was added to the PCR reaction and incubated at $72{ }^{\circ} \mathrm{C}$ for 9 min to insure the addition of the single $3^{\prime}$-A overhang. The PCR product was subcloned into pCRII-TOPO (Invitrogen), and plasmid minipreps were screened by Eco RI digestion. The sequence of one of these inserts was then determined using the Big Dye Terminator Cycle Sequencing Kit (PE Applied Biosystems) and analyzed at the Ohio University Sequencing Facility.

\subsection{Rapid amplification of cDNA ends (RACE)}

RACE-ready cDNA was synthesized using the SMART RACE cDNA Amplification Kit (Clontech) and SMART MMLV reverse transcriptase (Clontech) with $0.15 \mu \mathrm{g}$ day 0 , fifth instar larval midgut RNA in $10 \mu \mathrm{l}$ volume. The reactions were terminated by addition of $20 \mu \mathrm{l}$ Tricene-EDTA buffer (Clontech) and reactions were stored at $-20{ }^{\circ} \mathrm{C}$.

The following gene-specific primers were designed based on the sequence of the RT-PCR product:

\section{3'-RACE primer-1: 5'-GGTGTCCGTTCTGACGCTGACGTTC-3' 3'-Nested RACE primer-1: 5'-TACGCGATCGTCGGCCCGCTCA AGT-3' \\ 3'-RACE primer-2: 5'-TCCATCGTCTCCAAATGCCCAAACC-3' \\ 3'-Nested RACE primer-2: 5'-GGCGGACTGAGGTGTAGG \\ TGGACGA-3' \\ 5'-RACE primer-1: 5'-GAACGTCAGCGTCAGAACGGACACC-3' \\ 5'-Nested RACE primer-1: 5'-TTTTGCACAGCACGTCTCCA-3' \\ 5'-Nested RACE primer-2: 5'-CGATGCAGACCAAGGCATTCC CTA-3}

All RACE reactions were conducted using $2.5 \mu$ of RACE-ready cDNA using reaction conditions recommended in the SMART cDNA Amplification Kit. After an initial denaturation step at $94{ }^{\circ} \mathrm{C}$ for $4 \mathrm{~min}$, the mixtures were amplified for 3 cycles $\left(94{ }^{\circ} \mathrm{C}, 30 \mathrm{~s}\right.$; $\left.70{ }^{\circ} \mathrm{C}, 30 \mathrm{~s} ; 72{ }^{\circ} \mathrm{C}, 4 \mathrm{~min}\right)$, followed by 3 cycles $\left(94^{\circ} \mathrm{C}, 30 \mathrm{~s} ; 68^{\circ} \mathrm{C}\right.$, $\left.30 \mathrm{~s} ; 72{ }^{\circ} \mathrm{C}, 4 \mathrm{~min}\right)$, followed by 3 cycles $\left(94^{\circ} \mathrm{C}, 30 \mathrm{~s} ; 65^{\circ} \mathrm{C}, 30 \mathrm{~s}\right.$; $\left.72{ }^{\circ} \mathrm{C}, 4 \mathrm{~min}\right)$, followed by 33 cycles $\left(94^{\circ} \mathrm{C}, 30 \mathrm{~s} ; 60{ }^{\circ} \mathrm{C}, 30 \mathrm{~s} ; 72^{\circ} \mathrm{C}\right.$, $4 \mathrm{~min}$ ), followed by a $5 \mathrm{~min}$ final extension at $72^{\circ} \mathrm{C}$. All nested RACE reactions were conducted using $5 \mu$ of a 1:50 dilution of the RACE product as template. After an initial denaturation step at $94{ }^{\circ} \mathrm{C}$ for $4 \mathrm{~min}$, the mixtures were amplified for 20 cycles $\left(94^{\circ} \mathrm{C}, 30 \mathrm{~s} ; 68^{\circ} \mathrm{C}\right.$, $30 \mathrm{~s} ; 72{ }^{\circ} \mathrm{C}, 3 \mathrm{~min}$ ), followed by a $5 \mathrm{~min}$ final extension at $72^{\circ} \mathrm{C}$.

To determine the $3^{\prime}$-sequence, 3'-RACE-ready cDNA was amplified with the Universal Primer A Mix (UPM, Clontech) and 3'-RACE primer-1 as the gene-specific primer. A nested RACE was then performed using the Nested Universal Primer A (NUP) and 3'-Nested RACE primer-1. The $2.1 \mathrm{~kb}$ RACE product was cloned into pCR2.1 (Invitrogen) and sequenced. Since this product did not contain the poly-A sequence, a second $3^{\prime}$-RACE reaction was performed with UPM and $3^{\prime}$-RACE primer-2, followed by a nested RACE using NUP and 3-Nested RACE primer-2. The 600 bp product was cloned into pCR2.1 (Invitrogen) and sequenced.

\subsection{Sequencing and phylogenetic analysis}

Sequences were determined using the Big Dye Terminator Cycle Sequencing Kit (PE Applied Biosystems) and analyzed at the Ohio University Sequencing Facility. Transmembrane domains were predicted using TMHMM v. 2.0 (Krogh et al., 2001). Sequences were aligned using CLUSTALW MEGA version 4 software was used to construct a Neighbor-joining tree. For node support, bootstrap analysis was performed using 500 replicates. The evolutionary distances were computed using the Poisson substitution method.

\subsection{Expression and analysis of ATR}

The full-length ATR coding region was amplified using approximately $3 \mathrm{ng}$ of cDNA prepared from day 0 fifth instar larval midgut RNA with $0.4 \mu \mathrm{M}$ of a sense primer 5'-CACCATGCTTAACAAAAGCATA-3' and antisense primer 5'-CTAAGCGTAATATCCACTCTTAAATCC $-3^{\prime}$ using the AccuPrime Taq DNA Polymerase System (Invitrogen) in a $25 \mu$ l volume. After an initial denaturation step at $95^{\circ} \mathrm{C}$ for $5 \mathrm{~min}$, the DNA was amplified for 35 cycles $\left(95^{\circ} \mathrm{C}\right.$, $\left.30 \mathrm{~s} ; 50^{\circ} \mathrm{C}, 30 \mathrm{~s} ; 68^{\circ} \mathrm{C}, 2 \mathrm{~min}\right)$, followed by a $10 \mathrm{~min}$ final extension at $68{ }^{\circ} \mathrm{C}$. The $1.3 \mathrm{~kb}$ PCR product was cloned into the pcDNA 3.1 Directional TOPO Expression Vector (pcDNA3.1D, Invitrogen) to obtain the ATR expression plasmid, pcDNA3.1D-Manse-ATR. The orientation of the insert was verified by diagnostic Bgl II digestion and sequencing using the T7 and BGH primers which flank the insert, and internal primers. Plasmid DNA was purified using the EndoFree Plasmid Maxi Kit (Qiagen).

\subsection{Peptides}

Manse-AT and Manse-AKH were obtained from Bachem. F7D and F7G were generously provided by Dr. Jane Witten, University of Wisconsin, Milwaukee. FMRFamide and corazonin were obtained from Sigma. Manse-ATL peptides were custom synthesized by Research Genetics. Peptide stocks were prepared in 10\% acetonitrile and diluted in DMEM/F12 without phenol red supplemented with 0.1\% BSA. Peptide concentrations of the stocks were determined using the BCA Assay (Pierce), and Manse-AT and the Manse-ATL peptides were checked for correct mass by MALDI-TOF-MS.

\subsection{Cell culture and transfections}

Chinese hamster ovary (CHO) WTA11 and PAM28 cells stably expressing apoaequorin (Euroscreen, Belgium) and human embryonic kidney (HEK) 293 cells were cultured in monolayers in Dulbecco's Modified Eagles Medium nutrient mixture F12-Ham (DMEM/F12) (Sigma) supplemented with 10\% heat-inactivated fetal calf serum (Invitrogen), $100 \mathrm{IU} / \mathrm{ml}$ penicillin and $100 \mu \mathrm{g} / \mathrm{ml}$ streptomycin (Invitrogen). For CHO-WTA11 cells, $250 \mathrm{mg} / \mathrm{ml}$ Zeocin (Invitrogen) was added to the medium; and for CHO-PAM28 cells, $5 \mu \mathrm{g} / \mathrm{ml}$ puromycin (Sigma) was added to the medium. The cells were cultured at $37{ }^{\circ} \mathrm{C}$ with a constant supply of $5 \% \mathrm{CO}_{2}$.

Transfections with pcDNA3.1D-Manse-ATR or pcDNA3.1D (empty vector) were carried out in T75 flasks at 60-80\% confluency. The transfection medium for CHO-WTA11 or CHO-PAM28 cells was prepared according to the manufacturer's protocol with $703 \mu \mathrm{l}$ serum-free DMEM/F12, $46.8 \mu \mathrm{l}$ FuGENE 6 (Roche), and $7.8 \mu \mathrm{g}$ of pcDNA3.1D-Manse-ATR (or empty vector) and added dropwise to $3.5 \mathrm{ml}$ of the cell culture following $30 \mathrm{~min}$ incubation at room temperature. The transfection medium for the HEK293 cells was prepared according to the manufacturer's protocol with $200 \mu \mathrm{l}$ serum-free DMEM, $10 \mu$ l Dreamfect Gold (OZ Biosciences) and $2.5 \mu \mathrm{g}$ of plasmid DNA. The plasmid DNA consisted of $2.0 \mu \mathrm{g}$ of pcDNA3.1D-Manse-ATR (or pcDNA3.1D) and $0.5 \mu \mathrm{g}$ of a reporter gene plasmid. The reporter gene is luciferase ORF downstream of a cyclic AMP (CAMP) response element (CRE). This transfection medium was then added dropwise to $2.5 \mathrm{ml}$ of cell culture medium. The cells were incubated overnight, after which $10 \mathrm{ml}$ of cell culture medium was added to allow an additional overnight growth period prior to the monitoring of $\mathrm{Ca}^{2+}$ or cAMP.

\subsection{Aequorin assay}

Cells were detatched using $1 \times$ Phosphate Buffered Saline (PBS) containing $0.2 \%$ EDTA ( $\mathrm{pH} 8.0$ ), and rinsed off the flask with DMEM/ 
F12. The number of viable and nonviable cells were determined using a NucleoCounter NC-100 (Chemometic). The cells were pelleted for $4 \mathrm{~min}$ at $150 \mathrm{~g}$ at room temperature and resuspended in DMEM/F12 without phenol red (Gibco), and with L-glutamine and 15 mM HEPES supplemented with 0.1\% BSA (Sigma) (BSA medium) at a concentration of $5 \times 10^{6}$ cells/ml. Coelenterazine $\mathrm{h}$ (Invitrogen) was added to a concentration of $5 \mu \mathrm{M}$ and cells were incubated in the dark at room temperature with gentle shaking for $4 \mathrm{~h}$. The cells were then diluted 10-fold in BSA medium and incubated for an additional $30 \mathrm{~min}$ in the dark with gentle shaking. Peptides were dissolved in BSA medium and dispensed in $50 \mu \mathrm{l}$ aliquots into the wells of a white 96-well plate. After injection of $50 \mu \mathrm{l}$ of the cell suspension into each well, light emission was recorded using Mithras LB940 (Berthold Technologies) for 30 s. The cells were then lysed by injection of $50 \mu \mathrm{l} 0.3 \%$ Triton X-100 and light emission was monitored for an additional $8 \mathrm{~s}$ as a measure of the total cellular $\mathrm{Ca}^{2+}$ response. BSA media was used as a negative control in each row, and $1 \mu \mathrm{M}$ ATP, which activates an endogenous ATP receptor in $\mathrm{CHO}$ cells, was used to check the functional response. The total response (ligand + Triton X-100) is representative of the number of cells present in the well. The BSA media response (blank) was subtracted from the wells of the same row. Calculations were made using the output file using MikroWin software (Mikrotek) in Excel (Microsoft). Further analysis was done in GraphPad Prism 5.

\section{9. cAMP reporter assay}

Cells were detatched with $1 \times$ PBS containing $0.2 \%$ EDTA $(\mathrm{pH}$ 8.0), and rinsed off the flask with DMEM/F12. The cells were pelleted for $4 \mathrm{~min}$ at $150 \mathrm{~g}$ at room temperature and resuspended at a concentration of $1 \times 10^{6}$ cells/ml in DMEM/F12 without phenol red, but containing $200 \mu \mathrm{M}$ 3-isobutyl-1-methylxanthine (IBMX, Sigma) to prevent cAMP breakdown. Peptides were dissolved in DMEM/F12 media without phenol red containing $200 \mu \mathrm{M}$ IBMX in the presence or absence of $10 \mu \mathrm{M}$ forskolin (Sigma), and $50 \mu \mathrm{l}$ aliquots were dispensed into the wells of a white 96-well plate. Then $50 \mu \mathrm{l}$ of cells were added to the wells and the plate was incubated in a $\mathrm{CO}_{2}$ incubator at $37{ }^{\circ} \mathrm{C}$ for $3-4 \mathrm{~h}$. Then, $100 \mu \mathrm{l}$ of SteadyLite Plus (Perkin-Elmer) was added to each well and the plate was incubated for $15 \mathrm{~min}$ in the dark. Light emission resulting from the luciferase enzymatic activity was recorded for $5 \mathrm{~s} /$ well using Mithras LB940. Results were analyzed using MikroWin and further processed by Excel and GraphPad Prism 5 software.

\subsection{Quantitative RT-PCR}

Tissues from individual day 1 , fifth instar larvae or adults were dissected in Manduca saline buffer (Riddiford et al., 1979), transferred to an Eppendorf tube on dry ice and stored at $-80{ }^{\circ} \mathrm{C}$ in $500 \mu \mathrm{l}$ of TriReagent (Sigma). Tissues were homogenized using a plastic pestle and RNA was extracted as recommended by the manufacturer (Sigma). DNA was then digested with 0.04 units $/ \mu 1$ RNase-free DNase I (Ambion), and the absence of DNA was assessed by qPCR on randomly selected samples. Total RNA content was measured using RNA binding fluorescent dye and the Qubit fluorometer (Invitrogen). Then, $0.25 \mu \mathrm{g}$ of total RNA was used to synthesize cDNA with Moloney Murine Leukemia Virus (M-MLV) Reverse Transcriptase (Promega) and Random Primers (Promega) in the presence of Riboblock RNase Inhibitor (Fermentas).

The qPCR reaction was performed using cDNA synthesized from 5 ng RNA using $7.5 \mu \mathrm{l} 2 \times$ iTaq SYBR Green Supermix with ROX (BioRad) and 7.5 pmol of each primer in a final volume of $15 \mu$ l. The reaction was incubated for $2 \mathrm{~min}$ at $95{ }^{\circ} \mathrm{C}$, followed by 40 cycles ( $95{ }^{\circ} \mathrm{C}, 15 \mathrm{~s} ; 60{ }^{\circ} \mathrm{C}, 1 \mathrm{~min}$ ) in an Mx3000P thermal cycler (Stratagene). After the amplification steps, the specificity of the PCR products were assessed by generating a melting curve using the following conditions; $95^{\circ} \mathrm{C}, 15 \mathrm{~s}$; followed by $60^{\circ} \mathrm{C}, 1 \mathrm{~min}$; followed by an increase in temperature in $0.7{ }^{\circ} \mathrm{C}$ increments from $60{ }^{\circ} \mathrm{C}$ to $95{ }^{\circ} \mathrm{C}$. Primers were designed using Primer 3 software to have a $T_{\mathrm{m}}$ from $59-61{ }^{\circ} \mathrm{C}$, a $\mathrm{G}+\mathrm{C}$ content from 20 to $60 \%$, and to yield a product from 90 to $130 \mathrm{bp}$. The absence of RNA hairpins at the site of primer binding was confirmed using Mfold software (Zuker, 2003). The sequences of the primers used for Manse-ATR qPCR were 5'-TTCCTTGGAGACGTGCTGT-3' (forward - corresponding to nucleotides 558-575 of Fig. 1) and 5'-ACTTGAACTTGAGCGGG-3' (reverse - corresponding to nucleotides 688-672 of Fig. 1). The sequences of the primers used for the reference gene (rpS3) (Jiang et al., 1996) were $5^{\prime}$-CATGATCCACTCCGGTGAC-3' (forward) and 5'-GACCTTAATTCCGAGCACTCC-3' (reverse). The amount of ManseATR mRNA relative to rpS3 mRNA was determined using the $\Delta \Delta C_{T}$ quantification method (Livak and Schmittgen, 2001).

\section{Results}

\subsection{Isolation of an allatotropin receptor (ATR) $c D N A$}

The only insect in which an ATR has been characterized thus far is the silkworm, B. mori (Yamanaka et al., 2008). To identify an ATR from $M$. sexta, we designed degenerate oligonucleotide primers based on the sequence of the $B$. mori ATR cDNA (BNGR-A16) to amplify a portion of a putative $M$. sexta ATR cDNA using day 0,5 th instar larval cDNA. We used this tissue because the larval midgut is a known target of Manse-AT (Lee et al., 1998), and the large size of the larval midgut compared with the adult female CA facilitates the isolation of sufficient RNA as starting material. The amplification product of $\sim 600$ bp was sequenced and a TBLASTN search (Altschul et al., 1997) showed that the translated sequence exhibited the highest sequence identity to BNGR-A16, the ATR from B. mori (Yamanaka et al., 2008). Using the same poly $A^{+}$RNA preparation, we conducted 5'- and 3'-RACE to yield a cDNA of 3006 bp (excluding the poly A sequence) (Fig. 1). An in-frame stop codon is present 27 bases upstream from the first ATG, and a consensus sequence directing polyadenylation is present 16 bases upstream from the poly A sequence.

The cDNA encodes a protein of 457 amino acids which contains seven transmembrane domains characteristic of a $G$ proteincoupled receptor. A TBLASTN search showed that this sequence is most similar to BNGR-A16 (Yamanaka et al., 2008), exhibiting 82\% sequence identity in the region between TM-I and TM-VII (Fig. 2) suggesting that this is a receptor for allatotropin in $M$. sexta. Other insect proteins that exhibit a high level of identity include an additional GPCR from B. mori (BNGR-A5), which has not yet been functionally characterized, and GPCRs from Anopheles gambiae, Tribolium castaneum, N. vitripennis, and A. mellifera. The most similar mammalian protein was the orexin receptor which exhibited $48 \%$ identity with Manse-ATR in the region between TM-I and TM-VII.

\subsection{Functional characterization of ATR with Manse-AT and Manse-ATL-I, -II, and -III}

We initially expressed Manse-ATR in CHO-WTA11 cells (Euroscreen, Belgium). This cell line expresses the $\mathrm{Ca}^{2+}$ reporter apoaequorin and $G \alpha_{16}$, a promiscuous $G$ protein that couples most GPCRs to phospholipase $C \beta$ activation and subsequent mobilization of intracellular $\mathrm{Ca}^{2+}$ (Stables et al., 1997). Receptor-expressing cells exhibited dose-dependent $\mathrm{Ca}^{2+}$ responses to Manse-AT and each Manse-ATL peptide (Fig. 3B). All other peptides tested at $10 \mu \mathrm{M}$, including Manse-AKH (Ziegler et al., 1985), the FLRFamides F7G and F7D (Kingan et al., 1996), CCAP (Stangier et al., 1987), corazonin 
(Veenstra, 1989) and FMRFamide (Price and Greenberg, 1977), exhibited no response, demonstrating the specificity of the response of Manse-ATR to AT and the ATL peptides. The $\mathrm{EC}_{50}$ value for Manse-AT was $121.1 \mathrm{nM}$. Surprisingly, the ATL peptides showed significantly lower $\mathrm{EC}_{50}$ values. The $\mathrm{EC}_{50}$ values obtained were $0.54 \mathrm{nM}$ for Manse-ATL-I; $7.0 \mathrm{nM}$ for Manse-ATL-II; and $23.3 \mathrm{nM}$ for Manse-ATL-III. Only Manse-ATL-I functioned as a full agonist in this cell line, the other peptides behaved as partial agonists. Untransfected CHO-WTA11 cells or CHO-WTA11 cells transfected with pcDNA3.1D (empty vector) did not show any responses to ManseAT or Manse-ATL peptides.

To determine which second messenger pathway Manse-ATR couples with, we first expressed Manse-ATR in CHO-PAM28 cells. This cell line lacks $G \alpha_{16}$, thus causing the receptor to couple to its original second messenger pathway, but expresses apoaequorin to allow a test of whether receptor activation results in increased levels of intracellular $\mathrm{Ca}^{2+}$. Fig. $3 \mathrm{C}$ shows that Manse-AT and each Manse-ATL peptide specifically increases $\mathrm{Ca}^{2+}$ levels. The $\mathrm{EC}_{50}$ values obtained were $4.0 \mathrm{nM}$ for Manse-AT, $8.5 \mathrm{pM}$ for Manse-ATL-I, $37.2 \mathrm{pM}$, Manse-ATL-II, and $3.6 \mathrm{nM}$ for Manse-ATL-III. In this cell line, the $\mathrm{EC}_{50}$ values were significantly lower than those obtained in CHO-WTA11 cells, but the relative order of ligand potency was maintained. Each of these peptides behaved as full agonists. Untransfected CHO-PAM28 cells or CHO-PAM28 cells transfected with pcDNA3.1D (empty vector) did not show any responses to Manse-AT or Manse-ATL peptides.

We then tested whether activation of Manse-ATR is coupled to changes in cAMP levels. We expressed this receptor in HEK293

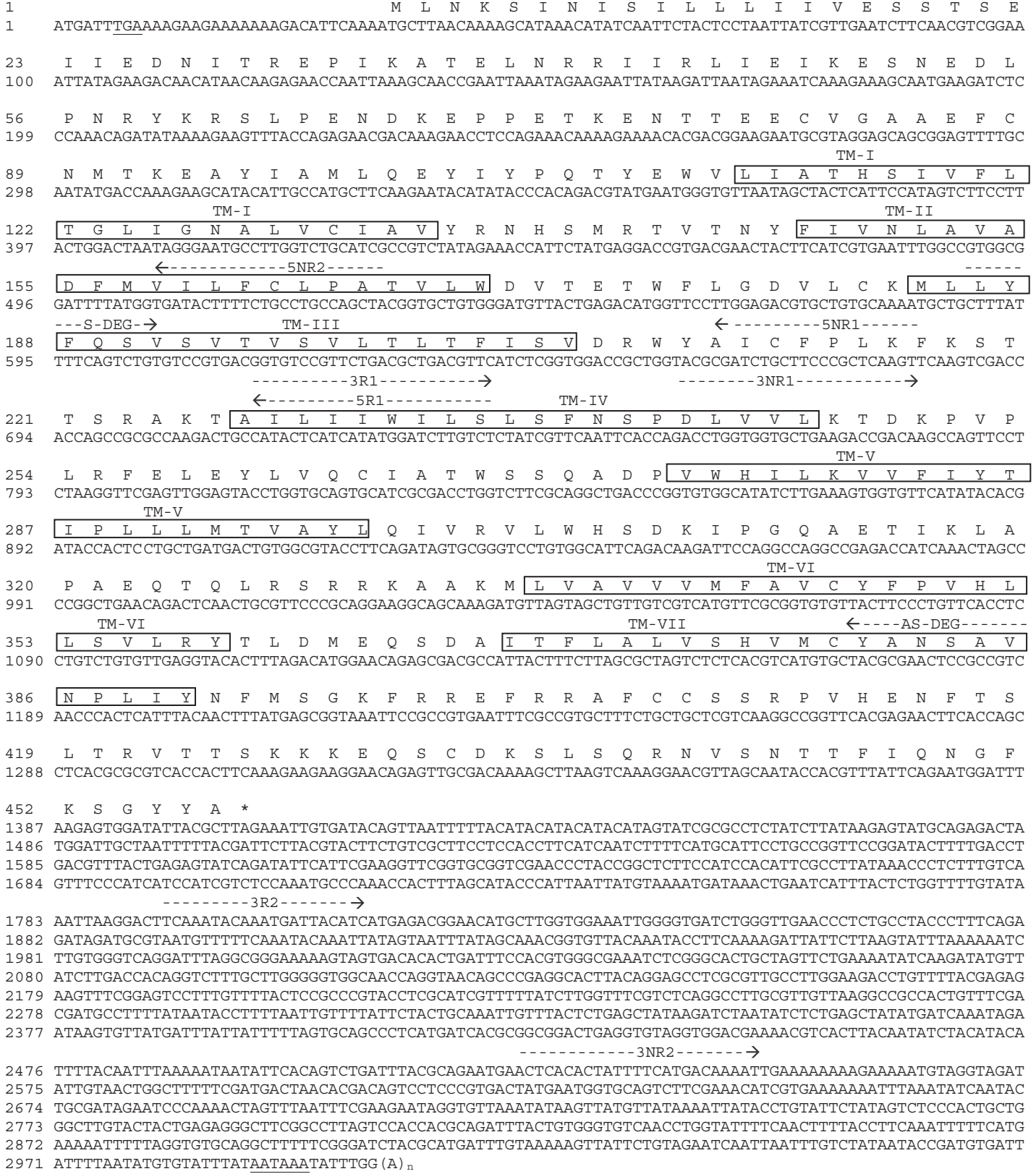

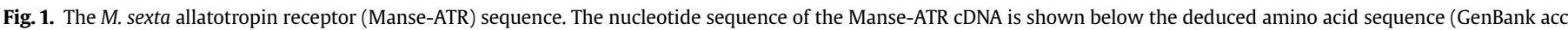

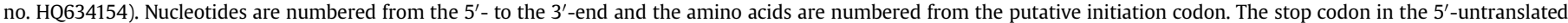

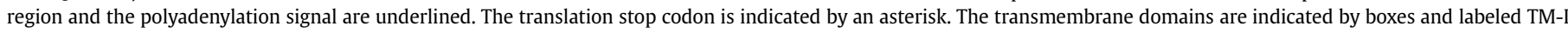

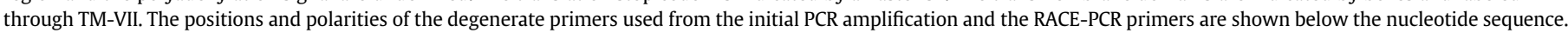


A

Manse-ATR BNGR-A16 BNGR-A5

Ag

Trica-ATR

$\mathrm{Nv}$

$\mathrm{HS}-\mathrm{OX} 2 \mathrm{R}$

Manse-ATR

BNGR-A16

BNGR-A5

Ag

Trica-ATR

$\mathrm{Nv}$

Am

$\mathrm{Hs}-\mathrm{OX} 2 \mathrm{R}$

Manse-ATR

BNGR-A16

BNGR - A 5

Ag

Trica-ATR

$\mathrm{Nv}$

$\mathrm{Am}$

$\mathrm{HS}-\mathrm{OX} 2 \mathrm{R}$

Manse-ATR BNGR-A16

BNGR-A5

Ag

Trica-ATR

Nv

Am

Hs-OX $2 \mathrm{R}$

Manse-ATR BNGR-A16 BNGR-A5

Ag

Trica-ATR

$\mathrm{Nv}$

$\mathrm{HS}-\mathrm{OX} 2 \mathrm{R}$

Manse-ATR BNGR-A16 BNGR-A5

Ag

Trica-ATR

$\mathrm{Nv}$

$\mathrm{HS}-\mathrm{OX} 2 \mathrm{R}$

Ag

B

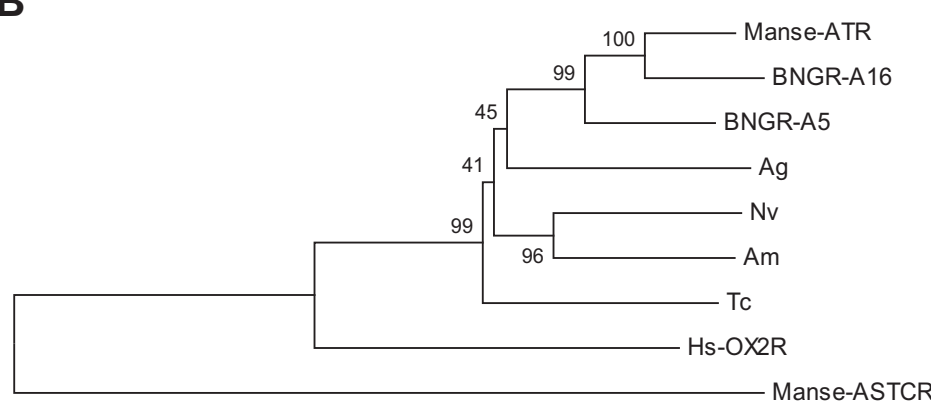
TM-I TM-III TM-VI

PSPRPAKL 511

Manse-ASTCR
- -MLNKSINISILLLII---VESSTSEIIEDNITREPIKATELNRRIIRL-IEIKESNEDLPNRYKRSLPENDKEPPEAKE----NTTEECVGAA 85 -MTTVEDDLNVPKKMKANKI - _. - _. - - ISEHDD - - -RFK- - - -TDTNSSEFEE- - -AENETCVGDP 48 MALRKESLAIITMLI ICNYVLSSNFDSIPESIRVRKSVDNTTSRSSLKNLNETMKOSNNE--TEFGR-LLDATEMTTEYDN----FTEEPCVGDR 88 - MTNASNVNPAEDLLVPFASNHSYTANGSAFWILKDLELATLQSPLEDN-HTTHSYPAVDLNDHNDVLCDDDSDQMEYNENCFIDHNVTCVGDP 92 - - - - - MLFFLLATILLSHAQAHDGLTSPHERANNSLFVSKPRP - - - -RNDTFIDDQFDY - - - LVRDKRDWDE- - - -DNASYINGS 69

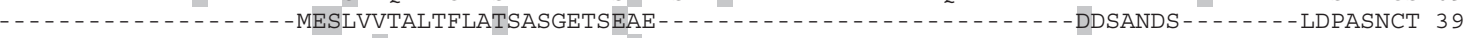
. $\ldots$ TM-II

EFCNMTKEAYIAMLQ-EYIYPQTYEWVLIATHSIVFLTGLIGNALVCIAVYRNHSMRTVTNYFIVNLAVADFMVILFCLPATVLWDVTETWFLGD 179 OYCNMTKEEYVKMIO-EYIYPNPYEWILIATHTFVFITGLFGNALVCVAVYRNHSMRTVTNYFIVNLAVADFMVILFCLPATVLWDVTETWFLGE 142 AFCNLTREEYMEMLN-DYVFPQPYEWVLIATHAIVFVIGLIGNALVCIAVYRNHSMRTVTNYFIVNLAVADFMVILICLPPTVLWDVTETWFFGT 182 DFCNLTYSEYRQLLM-DYIYPSTGEWILIASHTVVFLMGLVGNALVCIAVYTNHTMRTVTNIFIVNLAVADFFVILFCLPPTVVWDVTETWFMGK 186 GNVTFSEQEFIDSLW-ELIAPKSWTWILVILHSLVFI IGI I GNILVCVAVYRNHTMRTVTNYFIVNLAVADFLVILFCLPPSVVWDVTVTWFFGV 163 NNLCISEDEYLDEMH - AYIYPKSYEWVLIVLHCIVFIVGLVGNALVCLAVYRNHTMRTVTNYFIVNLAVADLLVIIICLPPTILWDITETWFLGL 133 NIYCISNEEYVDRMM-NYIFPKFWDWVLIASHSIVFVIGLIGNALVCIAVYRNHTMRTVTNYFIVNLAVADFLVLLLCLPFTVLWDITETWFLGL 131 NPTDYDDEEFLRYLWREYLHPKEYEWVLIAGYI IVFVVALIGNVLVCVAVWKNHHMRTVTNYFIVNLSLADVLVTITCLPATLVVDITETWFFGQ 124 TM-IV

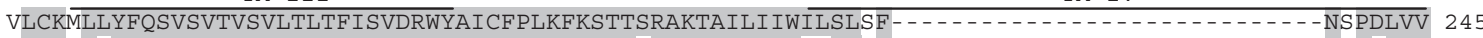

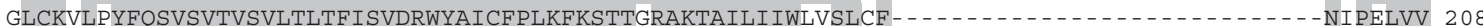
AMCRIVLYFQSVSVTVSVLTLTFISVDRWYAICFPLKFKSTTGRAKTAILIIWLLSLLF - $\ldots \ldots \ldots$ AMCKVVIYFQTVSVTVSVLTLTFISIDRWYAICFPLRYKPRPERAWRSIALIWLIGFLS- - - - - - - . - . - . - . - . - . - DLPEFLV 252 TMCKIVLYFQSVSVTVSVLTLTFISIDRWYAICFPLKFKSTTGRAKTAIGIIWIVALAC - - - - - - - - MPCKIVLYLQTVSVSVSVLTLTFISIDRWYAICFPLRFKSTTSRAKTAIIIIWVMALLF - - - . - . - . TLCKAVPYLQTVSVTVSILTLTFISIDRWYAICFPLRFKSTTGWAKNAIIGIWAIALLFGSYMHKIYCFSLNKQHYEKNHAPTLNVCADIPDLVV 226 SLCKVIPYLQTVSVSVSVLTLSCIALDRWYAICHPLMFKSTAKRARNSIVIIWIVSCII-- - - - - - - - - - - - - - - - - MIPQAIV 190 TM-V

LKTDKPVP-LRFELEYLVQCIATWSSQAD-PVWHILKVVFIYTIPLLLMTVAYLQIVRVLWHSDKIPGQAETIK- - - LAPAEQT- - - - - - - - - 324 LKLVRFVP-LR-ELPYLLQCYGTWSPSSE-LVWHILKVLLIYTLPLVLMAVAYHQIARVLWSSNGIPGQADTKK- - - LATAELT- - - - - - - - 286 LOVQTKMO-LRFNVOYFMOCASTWSDESD-LTWHI I KALFLYTFPLLLMTIAYCOIVRVLWRSDNIPGHTESHK----LCSTQTGQSNWLAASRR 337 LTTRR-KK-LRFDIKLFTQCVATWDNETE-KTFYIVKFVLLYTLPLLFMTVAYFQIVRVLWRSDTIPGHRESRNQPCGIHSTRTTLN- - - - - - - 336 VTTIP-TV-DEVDTVLLTQCAPTWSTETD-TIFFILKMVLFYLIPLLFMS IAYLQI IRVLWKSGNVPHQIMDASGGGGRQTNTFAMN- - - - - - 313 FYTHODRK-LHGKTILFTOCLPSWSRENQ - IAFNI I KLILLYTGPLMFMSFAYCOIVRVLWRND-IPGHNLSTR - - - I INANDLSSO - - - - - - - 280 LHTVPPTH-IKIKTILFTQCNISWSKKNQ-VIFIIVKLIFLYTGPLIFMSVAYWQIVKVLWKSD-IPGHNLSSR - - -ASQMSQIPP- - - - - - - - 306 MECSTVFPGLANKTTLFTVCDERWGGEIYPKMYHICFFLVTYMAPLCLMVLAYLQIFRKLWCRQIPGTSSVVQRKWKPLQPVSQPRG----PGQP 281 TM-VII

-QLRSRRKAAKMLVAVVVMFAVCYFPVHLLSVLRYTLDMEQS- - - DAITFLALVSHVMCYANSAVNPLIYNFMSGKFRREFR 402

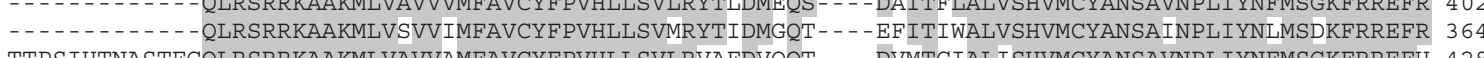
TTPS IHTNASTEGOLRSRRKAAKMLVAVVAMFAVCYFPVHLLSVLRVAFDVOOT- - - DVMTCIALISHVMCYANSAVNPLIYNFMSGKFRREFH 428 - - - CVGNTSTMGQLRARRKAAKMLVAVVIMFAGCYFPVHMLNVARYTVDIGQS- - - DIVAVLSLFSHWLCYANSAVNPVIYNFMSGKFRREFK 423 - - - - MNASTEGQLRSRRKAAKMLVAVVVMFAFCYFPVHLLSILRKTVGLKNT- - - DGNRAFSLISHWLCYANSAVNPI IYNFMSGKFRKEFH 398 - - - - SNVGNPEGQLKSRRKAAKMLVAVVLMFAVCCFPVHLLNILRSSIVIRSS - - - DLVNITSCLVHWLYYANSAINPLIYNFMSGKFRREFK 366 - - - - SGGGNPEVQLRSRKKAAKMLVTVVVIFAICYFPVHLLSVLRYTITLPSN - - - KWINAISLIAHGLCYFNSAVNPLIYNFMSGKRPLIFL 392 TKSRMSAVAAEIKQIRARRKTARMLMVVLLVFAI CYLPISILNVLKRVFGMFAHTEDRETVYAWFTFSHWLVYANSAANPI IYNFLSGKFREEFK 376

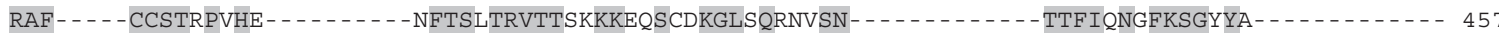
RAF- - - - CCSTSPGQQ - - - - - - - - DFTSMSRVTT--KKDSSIMASFKPGHTS - - - - - - - - - - - TTFVHN-NKNGHMT- - - - - - - - - - 415 RSYFKCFCCCHTTPAPEQNGASFEPIGSSRARTIRTTVRRHDSCVSYRLAHLSPSN-HNIHRDYIQNTNTSFIEPMNGNRRSKIRDESISDTATRF 523 NALEKCRCLRSSHAYGGR - - - - - -VGGYDDRSLCHTATRLN - - . - - - -VSPSTRSNYHLASVRDARFKVISNFFSSRAYCSVVPCLLIPNCCV 503 RAFEH - - -CCQRSGGHG - - - - - - - FQFSAVYRKTEKDSGIASRTHSRTDLEIQR - - - - - - - - -VNDFEPRHNRKGTKTSMLLVET- - - - - 464

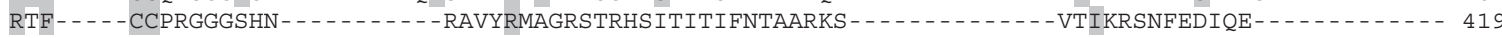

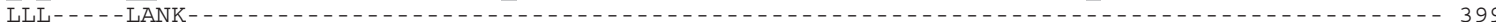
AAFS - - - CCCLGVHHRQEDRLTRGRTSTESRKSLTTQISNFDNISKLSEQVVLTS - - - - - - - - - - ISTLPAANGAGPLQNW - - - - - - - 444

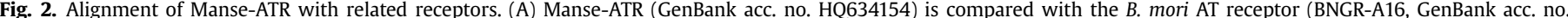

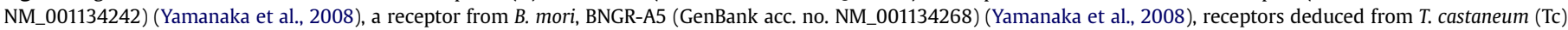

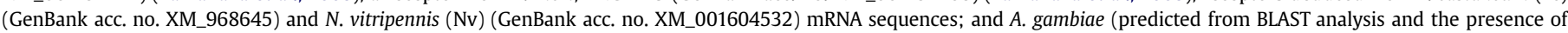

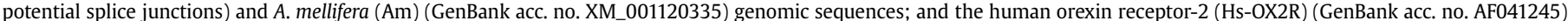

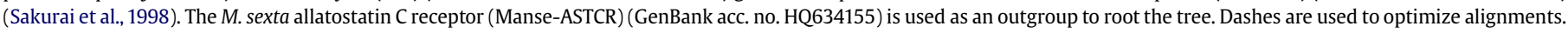

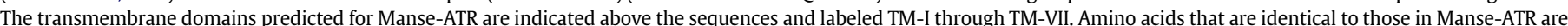

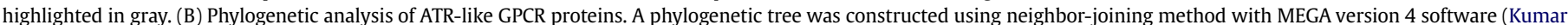
et al., 2007). Bootstrap values, shown next to each branch, were calculated using 800 replicates. Evolutionary distances were calculated using Poisson substitution model. 
cells. This cell line contains the luciferase gene under the control of a cyclic AMP response element (CRE). Cells were transfected with pcDNA3.1D-Manse-ATR or with pcDNA3.1D (empty vector) and cultured in the presence of the phosphodiesterase inhibitor IBMX. We assayed different concentrations of each peptide in the presence or absence of forskolin, which increases intracellular levels of cAMP. In the absence of forskolin, Manse-AT and each Manse-ATL resulted in a dose-dependent increase of cAMP concentration, measured by assaying luciferase activity (Fig. 3D). The $\mathrm{EC}_{50}$ values obtained were $76.5 \mathrm{nM}$ for Manse-AT, 46.2 fM for Manse-ATL-I, 5.1 pM Manse-ATL-II, and $0.37 \mathrm{nM}$ for Manse-ATL-III. The $\mathrm{EC}_{50}$ values measured in HEK293 cells were lower than in either of the other cell lines, but again, the relative order of ligand potency was maintained. When the peptides were tested in the presence of forskolin, there was no effect on cAMP levels. In this cell line, Manse-ATL-I and Manse-AT functioned as full agonists, but ManseATL-II and -III behaved as partial agonists. Untransfected HEK293 cells or HEK293 cells transfected with pcDNA3.1D (empty vector) did not show any responses to Manse-AT or Manse-ATL peptides, either in the presence or absence of forskolin.

\subsection{Expression of Manse-ATR}

We conducted an initial screen of tissue localization of ManseATR mRNA in feeding larvae by quantitative RT-PCR (qPCR) (Fig. 4A). The mRNA is most abundant in the Malpighian tubules suggesting a role for Manse-AT or the Manse-ATL peptides in control of water balance. A high level of Manse-ATR mRNA was also detected in the midgut which is consistent with the role of each of the peptide ligands on the inhibition of ion transport across the epithelium (Lee et al., 1998). Other tissues which contain high levels of Manse-ATR mRNA include the hindgut and the testes. All other tissues tested showed either low or undetectable levels of Manse-ATR mRNA. We obtained similar results when we used actin as the reference gene (data not shown).

We then determined the levels of Manse-ATR mRNA in the CA and CC of feeding larvae by qPCR (Fig. 4B). The mRNA levels were higher in the CA than in the CC, in contrast to B. mori when expression was observed only in the CC (Yamanaka et al., 2008). In adult insects, Manse-ATR mRNA was detected in the CC-CA complex of both females and males (Fig. 4B), although Manse-AT stimulates JH biosynthesis exclusively in female insects (Kataoka et al., 1989).

\section{Discussion}

In this study, we used the sequence of the B. mori ATR (BNGRA16) (Yamanaka et al., 2008) to design degenerate oligonucleotide primers to amplify a portion of the homologous cDNA from the larval midgut of $M$. sexta, and determined the full-length sequence following amplification of the $5^{\prime}$ - and $3^{\prime}$-ends using RACE. We predicted that the midgut from feeding $M$. sexta larvae would be a good source of Manse-ATR mRNA since Manse-AT robustly inhibits active ion transport across the larval midgut epithelium. This is in contrast to $B$. mori, in which both the response of the midgut to Manse-AT (Lee et al., 1998) and the mRNA level of BNGRA16 (Yamanaka et al., 2008) are quite low. We considered it highly likely that the cDNA isolated was a receptor for Manse-AT, since a TBLASTN search revealed that the sequence that exhibits the highest identity is BNGR-A16, the B. mori AT receptor. Several other insect receptors were identified using this TBLASTN search, notably a closely related receptor from $B$. mori designated BNGR-A5. BNGRA16 exhibits 73\% sequence identity with BNGR-A5 in the region between TM-I and TM-VII, and further differs from BNGR-A5 in the size and sequence of the $\mathrm{N}$-terminal and $\mathrm{C}$-terminal domains and by the insertion of 23 amino acids in BNGR-A5 in the third
A
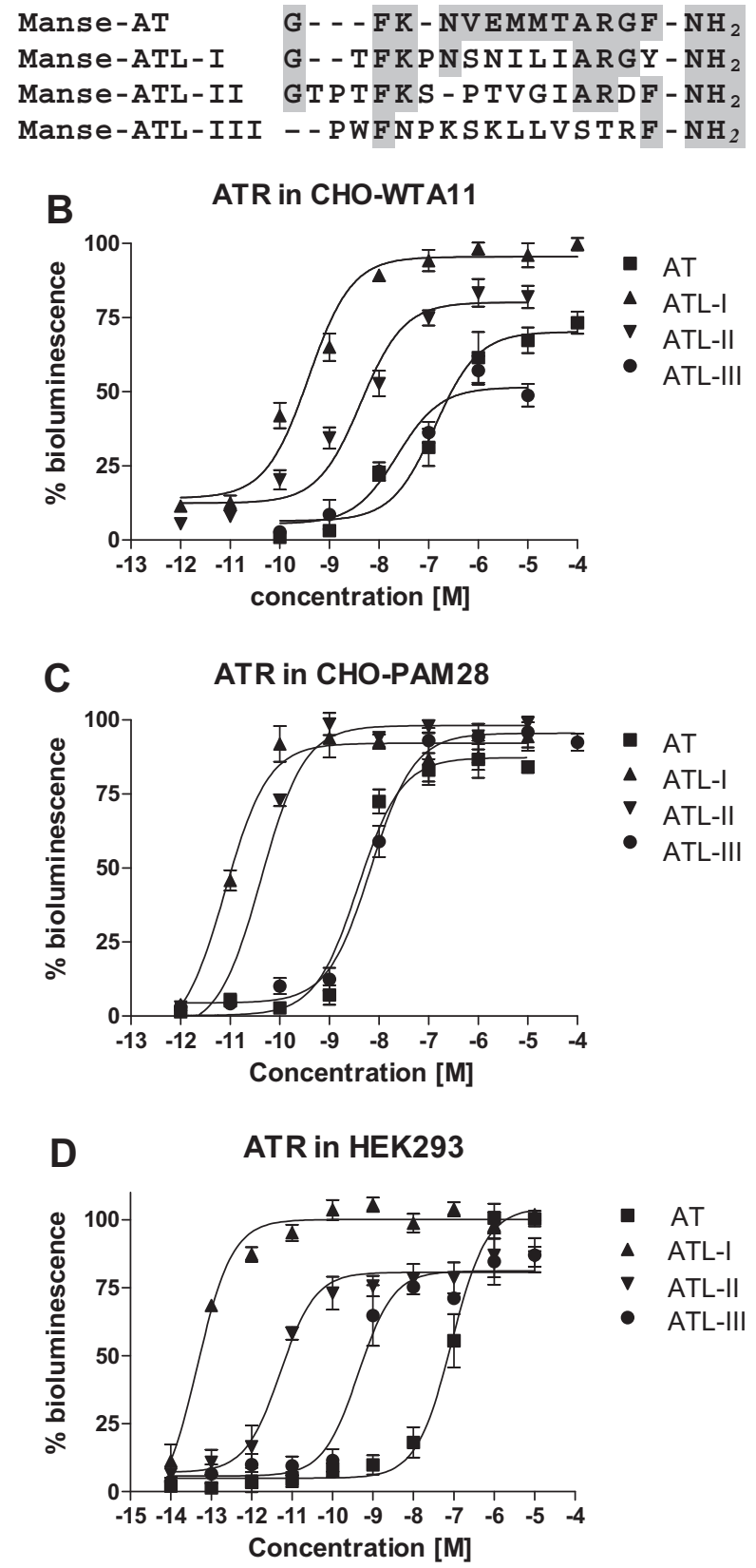

Fig. 3. Dose-response curves for responses of the effects of peptides in cells expressing Manse-ATR. (A) The sequences of the peptides assayed are aligned and amino acids that are identical to Manse-AT are highlighted in gray. Dose-response curve for bioluminescent responses induced in CHO-WTA11 (B), CHO-PAM28 (C) and HEK293 (D) cells expressing Manse-ATR. Data are the average \pm SD of three independent measurements done in triplicate and are expressed as percentage of the maximal response. The zero response level corresponds to treatment with buffer only. Peptides tested are Manse-AT ( $\boldsymbol{\square})$, Manse-ATL-I ( $\boldsymbol{\Delta}$ ), Manse-ATL-II ( $\boldsymbol{\nabla}$ ) and Manse-ATL-III ( $\bullet$ ). All other peptides tested at $10^{-5} \mathrm{M}$ did not activate the receptor.

intracellular loop located between transmembrane domains $\mathrm{V}$ and VI. The ligand binding specificity of BNGR-A5 has not yet been determined, and the expression profile during two larval stages differs considerably from that of BNGR-A16 (Yamanaka et al., 2008). In larvae, BNGR-A5 is expressed at the highest levels in the testis, while BNGR-A16 is expressed at the highest levels in several larval tissues including the brain, $\mathrm{CC}-\mathrm{CA}$, epidermis, and testis.

Other insect sequences identified in the TBLASTN search that exhibit high sequence identity with Manse-ATR include those 

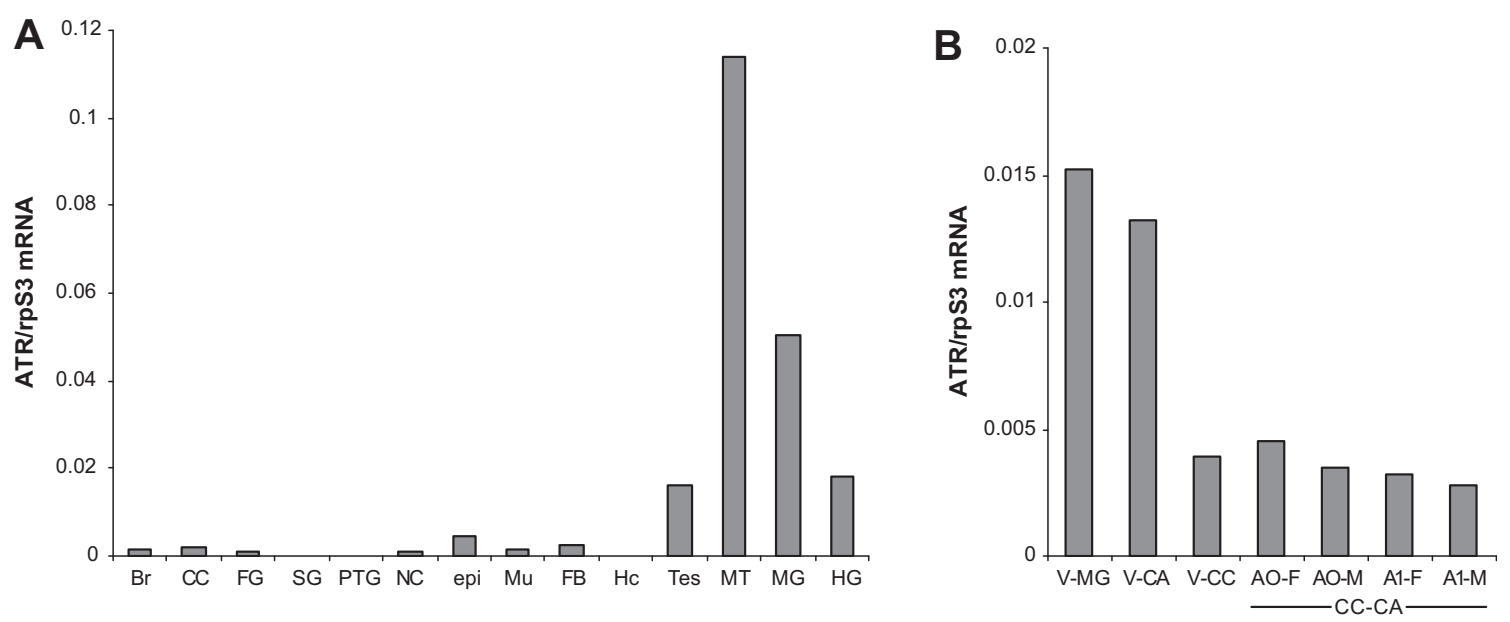

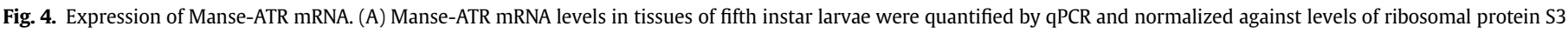

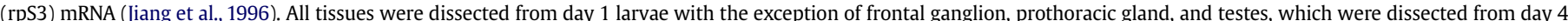

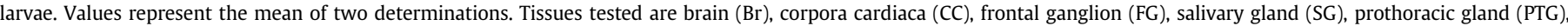

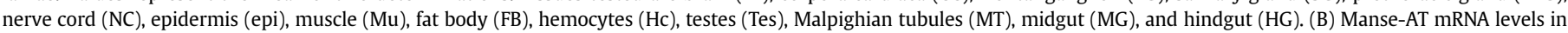

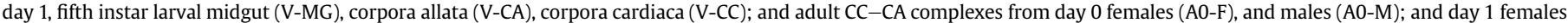
(A1-F) and males (A1-M) were quantified and normalized against levels of rpS3 mRNA.

deduced from mRNA sequences from $T$. castaneum and $N$. vitripennis, and those deduced from genomic sequences from $A$. mellifera and three mosquito species ( $A$. gambiae, Aedes aegypti and Culex pipiens). An AT sequence was deduced from the $T$. castaneum genome sequence (Amare and Sweedler, 2007; Li et al., 2008; Weaver and Audsley, 2008), and the peptide has been shown to stimulate JH biosynthesis in the beetle (Abdel-latief and Hoffmann, 2010), so the presence of a putative ATR was expected. Similarly, in A. aegypti and $A$. gambiae, an allatotropin has been identified which is similar in sequence to Manse-AT (Riehle et al., 2002; Veenstra and Costes, 1999), and which stimulates JH biosynthesis by the A. aegypti CA (Li et al., 2003). The absence of a similar receptor sequence was already noted in the $D$. melanogaster genome (Yamanaka et al., 2008) which is consistent with the absence of an allatotropin in this insect (Hewes and Taghert, 2001; Vanden Broeck, 2001). A similar sequence to Manse-ATR was unexpectedly found in $A$. mellifera and $N$. vitripennis, insects in which a peptide similar to Manse-AT has not been identified in silico using the genome sequence (Hummon et al., 2006) (Hauser et al., 2010). However, Manse-AT-like immunoreactivity was observed in numerous neurons in the CNS of $A$. mellifera, the axons of some terminated near the surface of the CA (Glasscock et al., 2005), and Manse-AT stimulates JH biosynthesis by the CA from feeding-stage larvae, although the peptide concentration required was in the $\mu \mathrm{M}$ range (Rachinsky and Feldlaufer, 2000) which may result from the use of a peptide from a heterologous insect. It is possible that a hymenopteran AT may have diverged from a Manse-AT-related sequence and acts through the GPCR similar to Manse-ATR. Further research is necessary to determine whether additional AT receptors exist, or whether structurally unrelated peptides act through Manse-ATR and the related GPCRs from other insects.

Examination of the alignments of the ATR (and orexin receptor) sequences (Fig. 2A) reveals the insertion of 29 amino acids in the A. mellifera sequence in a region that corresponds to transmembrane domain IV of Manse-ATR. Since the predicted A. mellifera sequence was deduced from the genome sequence, we tested for the presence of predicted splice donor and acceptor sequences flanking this insertion using the Splice Site Prediction by Neural network NNSPLICE 0.9 version (Reese et al., 1997), and no such sequence motifs were identified. Nevertheless, seven transmembrane domains, typical of a GPCR, were identified in the deduced protein using TMHMM, and the C-terminal portion of transmembrane IV was predicted to be localized within the 29 amino acid insertion.

The mammalian receptor that is most closely related to ManseATR is the receptor for orexin/hypocretin (Fig. 2A) (Sakurai et al., 1998). Orexins are two peptides, orexin A and orexin B, that exhibit limited sequence identity, but high structural similarity, and are derived from a common precursor protein (Sakurai et al., 1998; Voisin et al., 2003). Mammals contain two orexin receptors $\left(\mathrm{OX}_{1} \mathrm{R}\right.$ and $\mathrm{OX}_{2} \mathrm{R}$ ). $\mathrm{OX}_{1} \mathrm{R}$ is selective for orexin $\mathrm{A}$, but $\mathrm{OX}_{2} \mathrm{R}$ is activated by both orexins with similar potency (Sakurai et al., 1998). The best known functions of orexins are the regulation of wakefulness and feeding; but have additional roles in regulating neuroendocrine homeostasis and gut function (Voisin et al., 2003). Manse-AT does not exhibit sequence identity with orexins, but the sequence similarities between the receptors imply a potential evolutionary link between the two systems.

The Manse-AT gene is expressed as three alternatively spliced mRNAs (Taylor et al., 1996). Proteolytic processing of each translation product is predicted to yield Manse-AT mRNA, and the insertion of either one or two alternative exons in the longer Manse-AT mRNAs is predicted to yield allatotropin-like peptides (Manse-ATL-I, -II and -III, Fig. 3A) that are structurally related to Manse-AT (Horodyski et al., 2001). Alternative splicing of Manse-AT mRNAs is regulated in a stage- and tissue-specific manner and is predicted to yield a diverse set of peptide products that can vary in a dynamic manner during insect development (Horodyski et al., 2001; Lee et al., 2002). Similar alternative splicing of AT mRNAs and the existence of ATL peptides has been shown in several additional lepidopteran insects (Abdel-latief et al., 2003; Sheng et al., 2007; Yin et al., 2005).

It has been demonstrated that Manse-AT and the Manse-ATL peptides possess overlapping biological activities; Manse-AT and Manse-ATL-I stimulate JH biosynthesis by the adult female CA when tested at $20 \mathrm{nM}$, and each peptide inhibits ion transport across the larval midgut epithelium at $100 \mathrm{nM}$ (Lee et al., 2002). The overlapping set of bioactivities controlled by structurally similar peptides suggested that they act through a common receptor. Our data confirm this, and further show that the ATL peptides exhibit 
a greater potency toward Manse-ATR expressed in three different mammalian cell lines (Fig. 3). In each cell line, the most potent peptide was Manse-ATL-I, and the relative potencies for each of the peptides toward Manse-ATR were identical. The greater potency of the ATL peptides compared with Manse-AT suggests that this receptor might be a receptor for ATL peptides. However, it is clear from the data shown in Fig. 3. that Manse-AT is a ligand for this receptor in the nanomolar range. These data do not eliminate the possibility that an additional receptor may exist which has a greater affinity to Manse-AT. A candidate might be the homolog of BNGR$A 5$, if it is present in $M$. sexta, since it exhibits the greatest identity with BNGR-A16, the B. mori ATR. We have so far been unable to amplify cDNA for a second receptor using degenerate oligonucleotide primers. This possibility could be addressed in the future when the genome sequence of $M$. sexta is determined.

Despite the same order of potency, the $\mathrm{EC}_{50}$ values obtained varied considerably in the cell lines. This could be due to differences in receptor density, posttranslational modifications, or the presence or absence of interacting proteins that could affect the conformational and functional properties of a receptor. Therefore, tests with cloned receptors in heterologous cell lines might not fully reflect the actual situation in the insect. Although most neuropeptides generally function in the $\mathrm{nM}$ range, a much higher potency has been observed for Manse-AT using a foregut contraction bioassay. Manse-AT stimulates foregut contractions in $L$. oleracea at concentrations as low as $10^{-14} \mathrm{M}(10 \mathrm{fM})$ (Duve et al., 2000), and in $H$. armigera at concentrations as low as $10^{-16} \mathrm{M}(0.1 \mathrm{fM})$ (Duve et al., 1999). Aedae-AT stimulates hindgut contractions in Triatoma infestans at a concentration reported to be $10^{-18} \mathrm{M}$ (Santini and Ronderos, 2007).

The response of Manse-ATR is specific to Manse-AT and ManseATL peptides, since this receptor was not activated by any other peptide tested. This includes the FLRFamides F7G and F7D (Kingan et al., 1996). These peptides were tested because, like Manse-AT and Manse-ATL peptides, they also inhibit active ion transport across the larval midgut epithelium (Lee et al., 1998). The effects of ManseAT and the FLRFamides on the midgut are additive; the addition of FLRFamides to a Manse-AT-inhibited midgut resulted in additional inhibition of ion transport, whereas the addition of Manse-AT did not. This led to our hypothesis that Manse-AT and the FLRFamide act through distinct receptors on the basolateral membranes of the same midgut cells. The finding that F7G and F7D weakly activate the Bommo-myosuppressin receptor (Yamanaka et al., 2005) is consistent with this hypothesis.

In insects, the rate of $\mathrm{JH}$ biosynthesis is often correlated with an increase in the intracellular $\mathrm{Ca}^{2+}$ concentration of the CA cells (Allen et al., 1992; Rachinsky and Tobe, 1996; Rachinsky et al., 2003). In adult M. sexta, stimulation of JH biosynthesis is accompanied by increased levels of inositol phosphates (Reagan et al., 1992). In another lepidopteran insect, Heliothis virescens, a calcium ionophore mimics the effect of Manse-AT and a $\mathrm{Ca}^{2+}$ chelator antagonized the stimulatory effects of Manse-AT, suggesting that the peptide affects $\mathrm{JH}$ biosynthesis by increasing intracellular $\mathrm{Ca}^{2+}$ concentrations (Rachinsky et al., 2003). Our observation that the activation of the Manse-ATR in CHO-PAM28 cells is coupled to an increase in $\mathrm{Ca}^{2+}$ levels (Fig. 3B) is consistent with these previous studies, and suggests that the Manse-ATR acts through $\mathrm{G} \alpha_{\mathrm{q} / 11}$. The increase in cAMP levels in HEK293 cells by activation of Manse-ATR (Fig. 3C) indicates that it may also be coupled through a distinct $\mathrm{G} \alpha_{\mathrm{s}}$ second messenger pathway. Further studies will be needed to determine whether this multiplicity of $G$ protein coupling is genuine or due to the high receptor densities generated in transfected cells.

Our initial investigation into the tissue-specific profile of ManseATR expression in feeding larvae clearly demonstrated that the highest level of mRNA was seen in the Malpighian tubules (Fig. 4A). This tissue is generally not thought of as a target tissue for AT, but Manse-AT has been shown to inhibit fluid secretion by larval M. sexta Malpighian tubules (G.M. Coast, personal communication). Furthermore, Manse-AT caused an increase in acid phosphatase and alkaline phosphatase levels in Malpighian tubules of the Colorado potato beetle, Leptinotarsa decemlineata (Yi and Adams, 2001). This effect of AT mimics the effects of a JH analog, so it was thought that it was due to its effects on JH synthesis. However, it is possible that Manse-AT may act directly on the Malpighian tubules in L. decemlineata (Elekonich and Horodyski, 2003). The high level of Manse-ATR mRNA in the larval midgut (Fig. 4A) is consistent with the activity of Manse-AT and Manse-ATL peptides in the inhibition of active ion transport across the midgut epithelium (Lee et al., 1998). It will be interesting to determine whether the stage-specific effect of these peptides on midgut ion transport is due to fluctuating levels of Manse-ATR which may be reflected in changes in mRNA levels. Significant levels of Manse-ATR mRNA were also detected in the testes (Fig. 4A), suggesting that Manse-AT has a role in the male reproductive system which has not yet been characterized.

The first described target of Manse-AT is the adult female CA in which the peptide stimulates JH biosynthesis (Kataoka et al., 1989). Consistent with this activity, Manse-AT mRNA was detected in the adult female CC-CA complex, although mRNA levels are lower than that observed in the larval midgut (Fig. 4B). Surprisingly, Manse-AT mRNA was also detected in adult male CC-CA (Fig. 4B) although the peptide is inactive in this tissue (Kataoka et al., 1989). This indicates that the sex-specific difference in the activity of Manse-AT is not due to mRNA levels of the receptor. Alternatively, a second ManseAT receptor might exist whose mRNA levels reflect the peptide's activity on the CA. In $M$. sexta larvae, Manse-AT mRNA levels were higher in the CA compared with the CC, which differs from B. mori, in which mRNA for the AT receptor was only detected in the CC (Yamanaka et al., 2008).

Further studies are also necessary to determine whether ManseATR mRNA levels undergo tissue-specific alterations during development, as has been shown for B. mori (Yamanaka et al., 2008). This would be consistent with the dynamic changes of the primary roles of this neuropeptide family that have been shown for insects (Elekonich and Horodyski, 2003; Weaver and Audsley, 2009).

\section{Acknowledgments}

This research was supported by a grant from the National Science Foundation IOS-0821930 and research support from the Ohio University College of Osteopathic Medicine Research Committee to F.M.H. We thank M. Parmentier (University of Brussels, Belgium) and M. Detheux (Euroscreen S.A., Belgium) for providing CHO-WTA11 and CHO-PAM28 cells. We gratefully acknowledge the Interuniversity Attraction Poles programs [Belgian Science Policy Grant (P6/14)] and the K.U. Leuven Research Foundation (GOA/11/02) for financial support. H.V. was supported by the BOF (special research fund) of the K.U. Leuven. We acknowledge grant support from BBSRC BB/E022529/1 to S.E.R. We are grateful for the technical assistance from Joost Van Duppen and Luc Vanden Bosch. We thank Dr. Fernando Noriega for sharing the predicted $A$. gambiae ATR sequence. The accompanying paper by Vuerinckx et al. describes the characterization of an allatotropin/ orexin receptor in Tribolium castaneum.

\section{References}

Abdel-latief, M., Hoffmann, K.H., 2010. Neuropeptide regulators of the juvenile hormone biosynthesis (in vitro) in the beetle, Tenebrio molitor (Coleoptera, Tenebrionidae). Arch. Insect Biochem. Physiol. 74, 135-146. 
Abdel-latief, M., Meyering-Vos, M., Hoffmann, K.H., 2003. Molecular characterization of cDNAs from the fall armyworm Spodoptera frugiperda encoding Manduca sexta allatotropin and allatostatin preprohormone peptides. Insect Biochem. Mol. Biol. 33, 467-476.

Allen, C.U., Herman, B., Granger, N.A., 1992. Fura-2 measurement of cytosolic free $\mathrm{Ca}^{2+}$ concentration in corpus allatum cells of larval Manduca sexta. J. Exp. Biol. $166,253-266$

Altschul, S.F., Madden, T.L., Schäffer, A.A., Zhang, J., Zhang, Z., Miller, W. Lipman, D.L., 1997. Gapped BLAST and PHI-BLAST: a new generation of protein database search programs. Nucleic Acids Res. 29, 3389-3402.

Amare, A., Sweedler, J.V., 2007. Neuropeptide precursors in Tribolium castaneum. Peptides 28, 1282-1291.

Audsley, N., Weaver, R.J., Edwards, J.P., 2000. Juvenile hormone biosynthesis by corpora allata of larval tomato moth, Lacanobia oleracea, and regulation by Manduca sexta allatostatin and allatotropin. Insect Biochem. Mol. Biol. 30, 681-689.

Bell, R.A., Joachim, F.A., 1976. Techniques for rearing laboratory colonies of tobacco hornworms and pink bollworms. Ann. Entomol. Soc. Am. 69, 365-373.

Don, R.H., Cox, P.T., Wainwright, B.J., Baker, K., Mattick, J.S., 1991. 'Touchdown' PCR to circumvent spurious priming during gene amplification. Nucleic Acids Res. 19, 4008.

Duve, H., Audsley, N., Weaver, R.J., Thorpe, A., 2000. Triple co-localization of two types of allatostatin and an allatotropin in the frontal ganglion of the lepidopteran Lacanobia oleracea (Noctuidae): innervation and action on the foregut Cell Tissue Res. 300, 153-163.

Duve, H., East, P.D., Thorpe, A., 1999. Regulation of lepidopteran foregut movement by allatostatins and allatotropin from the frontal ganglion. J. Comp. Neurol. 413 405-416.

Elekonich, M.M., Horodyski, F.M., 2003. Insect allatotropins belong to a family of structurally-related myoactive peptides present in several invertebrate phyla. Peptides 24, 1623-1632.

Glasscock, J.M., Mizoguchi, A., Rachinsky, A., 2005. Immunocytochemical localization of an allatotropin in developmental stages of Heliothis virescens and Apis mellifera. J. Insect Physiol. 51, 345-355.

Harada, A., Yoshida, M., Minakata, H., Nomoto, K., Muneoka, Y., Kobayashi, M., 1993. Structure and function of the molluscan myoactive tetradecapeptides. Zool. Sci. 10, 257-265.

Hauser, F., Neupert, S., Williamson, M., Predel, R., Tanaka, Y. Grimmelikhuijzen, C.J.P., 2010. Genomics and peptidomics of neuropeptides and protein hormones present in the parasitic wasp Nasonia vitripennis. J. Proteome Res. 9, 5296-5310.

Hewes, R.S., Taghert, P.H., 2001. Neuropeptides and neuropeptide receptors in the Drosophila melanogaster genome. Genome Res. 11, 1126-1142.

Horodyski, F.M., Bhatt, S.R. Lee, K.-Y., 2001. Alternative splicing of transcripts expressed by the Manduca sexta allatotropin (Mas-AT) gene is regulated in a tissue-specific manner. Peptides 22, 263-269.

Hummon, A.B., Richmond, T.A., Verleyen, P., Baggerman, G., Huybrechts, J. Ewing M.A. Vierstraete, E. Rodriguez-Zas, S.L. Schoofs, L, Robinson, G.E. Sweedler, J.V., 2006. From the genome to the proteome: uncovering peptides in the Apis brain. Science 314, 647-649.

Jiang, H., Wang, Y., Kanost, M.R., 1996. Primary structure of ribosomal proteins S3 and S7 from Manduca sexta. Insect Mol. Biol. 5, 31-38.

Kataoka, H., Toschi, A., Li, J.P., Carney, R.L., Schooley, D.A., Kramer, S.J., 1989. Identification of an allatotropin from adult Manduca sexta. Science 243, 1481-1483.

Kingan, T.G., Shabanowitz, J., Hunt, D.F., Witten, J.L., 1996. Characterization of two myotropic neuropeptides in the FMRFamide family from segmental ganglia of the moth Manduca sexta: candidate neurohormones and neuromodulators. J. Exp. Biol. 199, 1095-1104.

Koladich, P.M., Tobe, S.S., McNeil, J.N., 2002. Enhanced haemolymph circulation by insect ventral nerve cord: hormonal control by Pseudaletia unipuncta allatotropin and serotonin. J. Exp. Biol. 205, 3123-3131.

Krogh, A., Larsson, B., von Heijne, G., Sonnhammer, E.L.L., 2001. Predicting transmembrane protein topology with a hidden Markov model: application to complete genomes. J. Mol. Biol. 305, 567-580.

Kumar, S., Dudley, J., Nei, M., Tamura, K., 2007. Molecular evolutionary genetics analysis (MEGA) software version 4.0. Mol. Biol. Evol. 24, 1596-1599.

Lee, K.-Y., Chamberlin, M.E., Horodyski, F.M., 2002. Biological activity of Manduca sexta allatotropin-like peptides, predicted products of tissue-specific and developmentally-regulated alternatively spliced mRNAs. Peptides 23 1933-1941.

Lee, K.-Y., Horodyski, F.M., Chamberlin, M.E., 1998. Inhibition of midgut ion transport by allatotropin (Mas-AT) and Manduca FLRFamide peptides in the tobacco hornworm, Manduca sexta. J. Exp. Biol. 201, 3067-3074.

Li, B., Predel, R., Neupert, S., Hauser, F., Tanaka, Y., Cazzamali, G., Williamson, M., Arakane, Y., Verleyen, P., Schoofs, L., Schachtner, J., Grimmelikhuijzen, C.J.P. Park, Y., 2008. Genomics, transcriptomics, and peptidomics of neuropeptides and protein hormones in the red flour beetle Tribolium castaneum. Genome Res. $18,113-122$.

Li, K.W., Holling, T., de With, N.D., Geraerts, W.P.M., 1993. Purification and characterization of a novel tetradecapeptide that modulates oesophagus motility in Lymnaea stagnalis. Biochem. Biophys. Res. Commun. 197, 1056-1061.

Li, S., Jiang, R.-J., Cao, M.-X., 2002. Allatotropic and allatostatic activities in extracts of brain and the effects of Manduca sexta allatotropin and Manduca sexta allatostatin on juvenile hormone synthesis in vitro by corpora allata from the Eri silkworm, Samia cynthia ricini. Physiol. Entomol. 27, 322-329.
Li, Y., Unnithan, G.C., Veenstra, J.A., Feyereisen, R., Noriega, F.G., 2003. Stimulation of $\mathrm{JH}$ biosynthesis by the corpora allata of adult female Aedes aegypti in vitro: effect of farnesoic acid and Aedes allatotropin. J. Exp. Biol. 206, 1825-1832.

Livak, K.J., Schmittgen, T.D., 2001. Analysis of relative gene expression data using real-time quantitative PCR and the $2^{- \text {DDCT }}$ method. Methods 25, 402-408.

Paemen, L., Tips, A., Schoofs, L., Proost, P., VanDamme, J., DeLoof, A., 1991. Lom-AGmyotropin: a novel myotropic peptide from the male accessory glands of Locusta migratoria. Peptides 12, 7-10.

Petri, B., Homberg, U., Loesel, R., Stengl, M., 2002. Evidence for a role of GABA and Mas-allatotropin in photic entrainment of the circadian clock of the cockroach Leucophaea maderae. J. Exp. Biol. 205, 1459-1469.

Price, D.A., Greenberg, M.J., 1977. Structure of a molluscan cardioexcitatory neuropeptide. Science 197, 670-671.

Rachinsky, A., Feldlaufer, M.F., 2000. Responsiveness of honey bee (Apis mellifera L.) corpora allata to allatoregulatory peptides from four insect species. J. Insect Physiol. 46, 41-46.

Rachinsky, A., Srinivasan, A., Ramaswamy, S.B., 2003. Regulation of juvenile hormone biosynthesis in Heliothis virescens by Manduca sexta allatotropin. Arch. Insect Biochem. Physiol. 54, 121-133.

Rachinsky, A., Tobe, S.S., 1996. Role of second messengers in the regulation of juvenile hormone production in insects, with particular emphasis on calcium and phosphoinositide signaling. Arch. Insect Biochem. Physiol. 33, 259-282.

Rankin, S.M., Kwok, R., Seymour, M.L., Rahman, U.S., Tobe, S.S., 2005. Effects of Manduca allatotropin and localization of Manduca allatotropin-immunoreactive cells in earwigs. Comp. Biochem. Physiol. 142B, 113-122.

Reagan, J.D., Miller, W.H., Kramer, S.J., 1992. Allatotropin-induced formation of inositol phosphates in the corpora allata of the moth, Manduca sexta. Arch. Insect Biochem. Physiol. 20, 145-155.

Reese, M.G., Eeckman, F.H., Kulp, D., Haussler, D., 1997. Improved splice site detection in genie. J. Comput. Biol. 4, 311-323.

Riddiford, L.M., 1994. Cellular and molecular actions of juvenile hormone I. General considerations and premetamorphic actions. Adv. In Insect Phys. 24 213-274.

Riddiford, L.M., Curtis, A.T., Kiguchi, K., 1979. Culture of the epidermis of the tobacco hornworm, Manduca sexta. Tissue Cult. Assoc. Man. 5, 975-985.

Riehle, M.A., Garczynski, S.F., Crim, J.W., Hill, C.A., Brown, M.R., 2002. Neuropeptides and peptide hormones in Anopheles gambiae. Science 298, 172-175.

Rudwall, A.J., Sliwowska, J., Nässel, D.R., 2000. Allatotropin-like neuropeptide in the cockroach abdominal nervous system: myotropic actions, sexually dimorphic distribution and colocalization with serotonin. J. Comp. Neurol. 428, 159-173.

Sakurai, T., Amemiya, A., Ishii, M., Matsuzaki, I., Chemelli, R.M., Tanaka, H., Williams, S.C., Richardson, J.A., Kozlowski, G.P., Wilson, S., Arch, J.R.S., Buckingham, R.E., Haynes, A.C., Carr, S.A., Annan, R.S., McNulty, D.E., Liu, W.-S. Terrett, J.A., Elshourbagy, N.A., Bergsma, D.J., Yanagisawa, M., 1998. Orexins and orexin receptors: a family of hypothalamic neuropeptides and $G$ proteincoupled receptors that regulate feeding behavior. Cell 92, 573-585.

Santini, M.S., Ronderos, J.R., 2007. Allatotropin-like peptide released by Malpighian tubules induces hindgut activity associated with diuresis in the Chagas disease vector Triatoma infestans (Klug). J. Exp. Biol. 210, 1986-1991.

Schwartz, L.M., Truman, J.W., 1983. Hormonal control of rates of metamorphic development in the tobacco hornworm Manduca sexta. Dev. Biol. 99, $103-114$.

Sheng, Z., Ma, L., Cao, M.-X., Li, S., Jiang, R.-J., 2007. Biochemical and molecular characterization of allatotropin and allatostatin from the Eri silkworm, Samia cynthia ricini. Insect Biochem. Mol. Biol. 37, 90-96.

Spittaels, K., Vankeerberghen, A., Schoofs, L., Proost, P., Van Damme, J., DeLoof, A., 1996. Isolation and characterization of Locusta migratoria accessory gland myotropin I (Lom-AG-MT-1) from the brain of the Colorado potato beetle. Arch. Insect Biochem. Physiol. 31, 149-155.

Stables, J., Green, A., Marshall, F., Fraser, N., Knight, E., Sautel, M., Milligan, G., Lee, M., Rees, S., 1997. A bioluminescent assay for agonist activity at potentially any G-protein-coupled receptor. Anal. Biochem. 252, 115-126.

Stangier, J., Hilbich, C., Beyreuther, K., Keller, R., 1987. Unusual cardioactive peptide (CCAP) from pericardial organs of the shore crab Carcinus maenas. Proc. Nat. Acad. Sci. U. S. A. 84, 575-579.

Taylor III, P.A., Bhatt, T.R., Horodyski, F.M., 1996. Molecular characterization and expression analysis of Manduca sexta allatotropin. Eur. J. Biochem. 239, 588-596.

Tu, M.-P., Kou, R., Wang, Z.-S., Stoffolano Jr., J.G., Yin, C.-M., 2001. Immunolocalization and possible effect of a moth allatotropin-like substance in a fly, Phormia regina (Diptera: Calliphoridae). J. Insect Physiol. 47, 233-244.

Ukena, K., Oumi, T., Matsushima, O., Ikeda, T., Fujita, T., Minakata, H., Nomoto, K., 1995. A novel gut tetradecapeptide isolated from the earthworm, Eisenia foetida. Peptides 16, 995-999.

Vanden Broeck, J., 2001. Neuropeptides and their precursors in the fruitfly, Drosophila melanogaster. Peptides 22, 241-254.

Veenstra, J.A., 1989. Isolation and structure of corazonin, a cardioactive peptide from the American cockroach. FEBS Lett. 250, 231-234.

Veenstra, J.A., Costes, L., 1999. Isolation and identification of a peptide and its cDNA from the mosquito Aedes aegypti related to Manduca sexta allatotropin. Peptides 20, 1145-1151.

Veenstra, J.A., Lehman, H.K., Davis, N.T., 1994. Allatotropin is a cardioacceleratory peptide in Manduca sexta. J. Exp. Biol. 188, 347-354. 
Voisin, T., Rouet-Benzineb, P., Reuter, N., Laburthe, M., 2003. Orexins and their receptors: structural aspects and role in peripheral tissues. Cell. Mol. Life Sci. 60, $72-87$.

Weaver, R.J., Audsley, N., 2008. Neuropeptides of the beetle, Tenebrio molitor identified using MALDI-TOF mass spectrometry and deduced sequences from the Tribolium castaneum genome. Peptides 29, 168-178.

Weaver, R.J., Audsley, N., 2009. Neuropeptide regulators of juvenile hormone synthesis. Ann. N. Y. Acad. Sci. 1163, 316-329.

Wyatt, G.R., Davey, K.G., 1996. Cell and molecular actions of juvenile hormone II. Roles of juvenile hormone in adult insects. Adv. In Insect Phys. 26, $1-155$.

Yamanaka, N., Hua, Y.-J., Mizoguchi, A., Watanabe, K., Niwa, R., Tanaka, Y., Kataoka, H., 2005. Identification of a novel prothoracicostatic hormone and its receptor in the silkworm, Bombyx mori. J. Biol. Chem. 280, 14684-14690.
Yamanaka, N., Yamamoto, S., Zitnan, D., Watanabe, K., Kawada, T., Satake, H., Hiruma, K., Tanaka, Y., Shinoda, T., Kataoka, H., 2008. Neuropeptide receptor transcriptome reveals unidentified neuroendocrine pathways. PLoS ONE 3, e3048.

Yi, S.-X., Adams, T.S., 2001. Age- and diapause-related acid and alkaline phosphatase activities in the intestine and Malpighian tubules of the Colorado potato beetle Leptinotarsa decemlineata (Say). Arch. Insect Biochem. Physiol. 46, 152-163.

Yin, H., Zhang, T.-Y., Xu, W.-H., 2005. Structural organization and expression analysis of the cDNA encoding allatotropin in the cotton bollworm, Helicoverpa armigera. Arch. Insect Biochem. Physiol. 60, 71-83.

Ziegler, R., Eckert, K., Schwarz, H., Keller, R., 1985. Amino acid sequence of Manduca sexta adipokinetic hormone elucidated by combined fast atom bombardment/ tandem mass spectrometry. Biochem. Biophys. Res. Commun. 133, 337-342.

Zuker, M., 2003. Mfold web server for nucleic acid folding and hybridization prediction. Nucleic Acids Res. 31, 3406-3415. 